\title{
Power among the Powerless: A Theoretical Approach to Understanding How (Legal) Power Appears among Persons Placed under Guardianship
}

\section{INTRODUCTION}

In my study, I seek to answer the question of how the institution of guardianship is presented in the lives of people placed under guardianship, their families, their support networks, and their guardians. Guardianship is a legal institution that encompasses all aspects of life. The law is much more present in the everyday lives of the people concerned than it is for people who do not have to deal with it.

According to cultural sociology, the law is not an absolute, institutional system, but part of everyday life and everyday culture. In this interpretative framework, law is part of reality even if it is not consciously perceived or defined (Swidler, 1986). At the same time, we cannot ignore the fact that law is a construct of power. It allows or forbids, it controls, it sets limits. One of Michel Foucault's fundamental propositions is that power is constructed in everyday life, permeating the totality of society and life (Foucault, 1999). If we therefore consider law as part of everyday life, not forgetting that it is also a significant factor of power, we can build a theoretical analytical framework that can help us to understand what the legal institution of guardianship really means for the people concerned and how law intervenes in their lives.

In what follows, I will first examine the Foucauldian theory of power through the lens of a cultural approach to legal studies, and then I will compare this with interviews with those affected by the institution of guardianship. The interviews were conducted within the framework of the ongoing research project: The Restricting of the Legal Capacity of Adults in Hungary, led by Prof. István Hoffman [OTKA FK132513].

\section{LAW AND POWER: ORDINARINESS AND ABSOLUTENESS}

The starting point of the cultural turn in jurisprudence is that law should be analysed as part of culture, in which law itself is a cultural factor. This turn puts the social theoretical approach to law on a completely new footing. On the one hand, it argues 
that law is not a separate subsystem but, on the contrary, an integral part of culture. This tradition of research goes back to Eugen Ehrlich's notion of living law, which distinguishes, especially at the periphery, between written law and the law used by individuals and communities. As Ehrlich puts it:

"Living law is not laid down in legal documents, yet it rules over life" (Ehrlich, 1977, 72).

Living law is thus a factor shaping social functioning and individual action, even in contrast to existing law. It can be understood by studying everyday legal texts, which are the source of the norms of living law, and not law books. Ehrlich's concept of living law and his work are not only the foundations of European sociology of law, but also one of the inescapable theoretical roots of modern cultural legal studies. (Ehrlich, 1977).

The cultural turn, therefore, shifts attention from the study of macro-social processes and institutional functioning to the everyday manifestation of law, in which the actor is at once an active, forming and reflective agent. Thus, instead of looking at the functioning of large social institutions, it examines the way in which "structure, culture and the actor interact to form each other" (Fleck et al., 2017, 11) and, at the same time, how they construct the realities of everyday life (Fleck et al., 2017). Sally Engle Merry in her paper - Getting Justice and Getting Even: Legal Consciousness among Working-Class Americans - examines the everyday legal problems of the American working class and finds that when a problem or a situation of harm arises, even the recognition of the problem as a right is a significant problem, which fundamentally calls into question the principle of equal access, or more precisely, its enforcement (Merry, 1990).

But the law also has a significant power dimension. In the Foucauldian approach, we can interpret law as a factor of power while remaining within a cultural framework, namely approach the law itself through the aspect of everyday life. In this interpretation, power emerges in the interactions of everyday life, manifesting itself in symbols, privileges, statuses, rather than a separate and distinguishable entity within society. (Ewick \& Silbey, 2003).

Understanding the nature of power is the heart of Foucault's entire oeuvre, and I am just about to highlight his thoughts on bio-power. In several of his writings, Foucault explores how the organization of power is transformed from control over territory to control over the body. In his work on "governance", he examines two ways of organizing power. The second of these is linked to the emergence of the modern administrative state. It is in this period (18th century) that the focus of governance shifts from the territory to the body of people, exercising power over their well-being. The exercise of power is rationalized and institutions such as the police, the prison and the hospital appear, covering all aspects of life. Thus, the point contact with power ceases to exist and becomes much more embedded in the experience of everyday life. The historical change of power, according to Foucault, has moved towards atomization, that is, power dynamics are increasingly understood at the individual level (Sik, 2009). As Foucault notes in The History of Sexuality, the meaning of power and with it, of law changes in this era, "power is exercised not by law but by normalization, not by punishment but by control" (Foucault 1999). This type of government is the era of the emergence of liberal states, one of whose mottos is that the purpose of government is "the right ordering of things" (Foucault 2000b). 
This does not mean, as Vikki Bell points out, that for Foucault, the emergence of the liberal state would mean that the individual becomes completely free, free from power dynamics, but on the contrary, it is a myth of the free person. In the case of the liberal state, since the system itself, based on indirect democracy, the structure of the state is an obstacle to complete freedom of action, even for a politically active man (Bell, 1996). In Foucault's interpretation, law becomes part of everyday life, power is transformed into a kind of technique. As he writes in Discipline and Punishment, in terms of the technique of the exercise of power, the medieval demonstration of force based on violence and spectacle is replaced by constant control (Foucault, 1990). In this way, anyone who does not fall into the categories of normality can be controlled, he writes in The History of Madness. Anyone whose behavior does not fit what is accepted by society is placed beyond normality, his or her life is more constrained. Power thus appears as control through normativity, embedded in everyday life, in all aspects of life (Foucault, 2004).

Thus, Foucault interprets law within these frameworks of the concept of micropower, but, as Alan Hunt points out, he fails to take into account the role of the state and power groups, and thus cannot interpret law according to its weight (Hunt, 1992). Foucault argues that in the power logic of the technique of discipline that weaves the fabric of society, law is rather formal and external. As a critique of this, Hunt argues that law is not the opposite of discipline, but rather its primary source (Hunt, 1992). "Power spreads through individuals, not through them, it finds its resting place in them" (Foucault, 2000a, 155). [Translated by the author. In Hungarian: "A hatalom az egyéneken keresztül árad szét, nem pedig rajtuk keresztül, bennük jut nyugvópontra."]

The legal institution of guardianship fits perfectly into this approach. It is through the guardianship system that an individual's capacity to act, and hence his freedom, is limited. By placing an individual under guardianship, he is removed from the "normal", and the state or society is given the right to control him.

\section{INTERVIEW IMPRESSIONS}

\subsection{The method}

In the following I will analyse how the legal institution of guardianship appears in some of the interviews. The interviews were conducted within the framework of the research project entitled The Restricting of the Legal Capacity of Adults in Hungary, in which we are interested in how the institution of guardianship appears in the life stories. For this purpose, we will conduct narrative life story interviews with caretakers, persons under guardianship and their supporting family members and friends. Our aim with this threefold split is to examine the legal institution of guardianship from as many aspects as possible, thus building a complex picture of its impact.

The interviews are narrative life-course interviews, a construct that is one of the least intrusive interview techniques. While most social science methods are more or less intrusive, the narrative life-course interview attempts to minimize this by reducing the role of the interviewer as far as possible and focusing on the role of the interview subject as far as possible. The interviewer simply explains the focus of the 
research and asks the interviewee to tell the story of his or her life. From then on, the interviewee leads the interview process, deciding how long he or she wants to talk and what he or she wants to say (Vajda, 2006).

In this approach, the narrative itself is the basis of the analysis, the social construction itself, which gives us the ability to reconstruct a kind of social structure based on the social reality and experiences of the individual (Kovács, 2011). Based on the narrative life story interview, we construct a hermeneutic case reconstruction, in which, following Rosenthal's approach, the analysis of the life story consists of two major parts, a hermeneutic case reconstruction of the lived life and a hermeneutic case reconstruction of the narrated life. For the analysis of the lived life, biographical data will be collected and arranged in chronological order. We then form hypotheses on it, considering the socio-historical context. The narrative life story is then examined. The text is broken down into sequences, but not transformed; everything is analyzed in the order in which the interviewee told it (Roshental, 1993).

However, this is not done here. In this paper, I present below some of the statements from the interviews, which could potentially support the cultural concept of rights and Foucauldian power theory described above. Thus, the analysis is methodologically unsupported, and this will be remedied in a later phase of the research. So, in this paper I will only report impressions from the interviews.

\subsection{Entries - interview narratives}

Nine interviews have been conducted so far during the research. The aim of the research is to interview people under guardianship, their guardians, and their supportive relatives, in order to get the most complex picture possible of the effects of incapacity. The following quotes are written without punctuation. The reason for this is that when we describe live speech, we are already interpreting it by punctuating it. To avoid this, narrative life history interviews should be handled with as little interference as possible, leaving out punctuation. In the following, I will try to show what this can mean in everyday reality, using a few examples.

Kristóf, a 20-year-old young man from Budapest, whom his father wanted to place under guardianship, because of an injury he had suffered at birth, which required nine brain operations. His parents will therefore start a guardianship procedure, a lawsuit, against him when he reaches the age of majority. Kristóf does not consider himself mentally or psycho-socially disabled at all, and he says that he wants to live an independent life. He describes his own situation as follows: "that's why my father will keep me on a very short leash, because for them, living with this illness in a normal environment is not possible, they don't look kindly on it, but I would like to live like a normal person."

It is interesting to note the juxtaposition of normal and not-normal, which is a feature of his language throughout the interview. Kristóf perceives that by being placed under guardianship he would fall outside the "normal" members of society, he would not be an equal member anymore.

He perceives the attempt to be placed under guardianship as an attack he is unprepared for. Although it is clear, that Kristóf is perfectly capable of understanding 
the legal process, he is struck by the fact that they argue about Kristóf without arguing about him at all.

"Why this guardianship was initiated is still unclear to me, because the fact that I was not informed about it, or only found out about it afterwards, is a dark hole, and neither the guardianship office nor my father and mother explained why it was necessary."

So even restrictions covering all aspects of life can start without the person concerned knowing anything about it, they are going over their head. Suddenly, the law intervenes in his life, looking at him as an external, offensive instrument.

László, seventy-five years old, who is both the guardian and the supporter of his own son. His son suffers from a psycho-social illness and was placed under guardianship as a young adult. László's son is in his forties at the time of the interview. László has a university degree, he is an intellectual freelancer and currently working in a high-level position. His experience of being taken into care by someone is very similar to Kristóf's. The proceedings will start when his son is once back in psychiatric care.

"The doctor suggested, it was an official suggestion, that he should be put under guardianship, we found out afterwards, because she didn't tell us and then the guardianship office started to hearing us and I said I didn't think we should, but they said it was ex officio and then the court ordered it because it was an official procedure that he should be put under guardianship [...], we even had a lawyer several times to say no."

Here again, the legal process is initiated without the person concerned, or without their family member being aware of it. László says several times during the interview that he and his son didn't want this guardianship, they had explicitly objected to it, but that they did not take it into account in the proceedings, only the expert's report. This is what he says about the guardianship: "my experience of guardianship itself has been negative, it has not helped but has been a hindrance"; "the institution of guardianship does not really help [...], it does more harm than good."

Not only does the law go over their heads, but it does not reflect the real problems either. László's son needs help in making certain decisions, and the family needs financial and social support, but this institution is lacking these. As László puts it, guardianship is just an administrative burden, it interferes with their daily lives and ties them together, it transforms the father-son relationship into a formal one, and it is not a help but a handicap.

Klára is in her forties, she has been a professional caretaker for eight years, in and around a small rural town. She makes a statement about the institution of guardianship in a mostly technical sense, mainly about how she buys to her client and how she helps with finances.

" $70 \%$ of my work is spent going into town, I have checks, I plan what I'm going to do and I write a weekly report on what I did."

Making joint decisions, the possibility of enabling does not even appear in the interview. At first glance, this is due not only to the outdated institutional system, but also to the fact that Klára has 40 caretakers in two settlements, far exceeding her strength.

She also speaks in a very technical way about guardianship and court proceedings, just describes it without reflection. Klára is there in the everyday lives 
of the wards. The scope of her intervention is more or less depending on the degree of limitation of her client's ability to act. She mainly talks about the financial problem and tasks, but also another thread appears: placing the people under guardianship in the institution as soon as possible.

"As soon as I receive the ward's application we will start applying for an institutional placement."

"The homeless shelter has indicated that he [a homeless person] will lose his money and also the homeless shelter has indicated to the guardianship authority that they wish to place him in custody."

The institution can dominate the wards' all areas of life, their freedom of choice is even more limited, their independent living is de facto lost. Of course, in some cases, institutional placement is the best solution, but strikingly, without any critical tone, it appears as a natural part of the process, as something inevitable in Klára's interview. It does not even appear if these people would be able to live independently, to make free decisions, or what kind of institutional help exists to live a freer life, it does not come to light.

\section{CONCLUSIONS: LAW AND POWER IN EVERYDAY LIFE}

I think that, although the above analysis is just a superficial summary of first impressions, two aspects could be the subject of further investigation. One is the way in which guardianship transforms human relationships and everyday life, and the other is the way in which the legal process intervenes in people's lives and how they experience it.

The real purpose of the legal institution of guardianship is to intrude into the life of the individual, and by limiting capacity to act, freedom of choice is infringed. At first sight, it seems clear from the interviews that the restriction or threat of restriction of capacity is a change in the level of everyday life, a diversion of life paths or a change in family relationships. The power over the body is seen as a limiting force that does not help but regulates and disciplines.

In Klára's interview, it is striking how this is normalized, how this intervention can be spoken of in purely technical terms and thus how what is actually happening, the fact that the freedom of the individual is violated, ignored. With this normalization, the intervention loses its scale, it becomes more and more neutral.

The legal process, in Kristóf and László's interview, is also a sudden event. Although they are the subjects of the procedure, it starts abruptly, the law looms over their heads. Of course, this can be a feature of law, criminal proceedings obviously start with the accused not consenting, or we can start a lawsuit for damages without asking the person who caused the damage. However, in the case of incapacity, there is no harm on the other side to justify it. Both Kristóf and László define the procedure almost as a punishment, the singling out of the "normal" of the individual. One may ask whether the very legal procedure by which the Hungarian legal system limits capacity is appropriate or whether it is worth reconsidering. 


\section{References}

Bell, V. (1996). The promise of liberalism and performance of freedom. In Barry A., Osborne T. \& Rose N. (eds). Foucault and Political reason. Liberalism, neo-liberalism and rationalities of government (pp. 81-99). Chicago: The University of Chicago Press. https://doi. org/10.4324/9781315072500

Ehrlich, E. (1977). A jogszociológia megalapozása. In Modern polgári jogelméleti tanulmányok (pp. 64-80). Budapest: MTA Állam- és Jogtudományi Intézet.

Ewick P. \& Silbey S. (2003). Narrating Social Structures: Stories of Resistance to Legal Authority. AJS, 108(6), 1328-1372. https://doi.org/10.1086/378035

Fleck Z. (2017). Kor és korszellem. In Fleck Z., Kiss V., Tóth F., Neumann L., Kenéz A. \& Bajnok D.: A jogtudat narratív elemzése. Budapest: ELTE Eötvös Kiadó.

Foucault, M. (1990). Felügyelet és büntetés. a börtön története. Budapest: Gondolat.

Foucault, M. (1999). A szexualitás története l. a tudás akarása. Budapest: Atlantisz Könyvkiadó.

Foucault, M. (2000a). A hatalom mikrofizikája. In Sutyák T. (ed.). Nyelv a végtelenhez. Tanulmányok, előadások, beszélgetések (pp. 307-330). Debrecen, Latin Betűk.

Foucault, M. (2000b): A „kormányozhatóság”. In Foucault, M: Fantasztikus könyvtár. Válogatott tanulmányok elöadások és interjúk. Budapest: Pallas Stúdió - Attraktor Kft.

Foucault, M. (2004). A bolondság története. Budapest: Gondolat.

Hunt, A. (1992). Foucault's Expulsion of Law. Toward a Retrieval. Law \& Social Inquiry, 17(1), 1-38. https://doi.org/10.1111/j.1747-4469.1992.tb00927.x

Kovács É. (2011). A narratív módszertanok politikája. Forrás, 43,(7-8),3-20.

Merry, S. E. (1990). Getting Justice and Getting Even: Legal Consciousness among WorkingClass Americans. Chicago: University of Chicago Press.

Rosenthal, G. (1993). Reconstruction of life stories: principles of selection in generating stories for narrative biographical interviews. The Narrative Study of Lives, 1(1), 59-91. https:// www.ssoar.info/ssoar/handle/document/5929 [Accessed: 31. 08. 2020.]

Sik D. (2009). A kommunikatív ész kritikája - Kommunikatív cselekvés és személyes identitás. Szociológia Szemle, 2009(3), 41-59.

Swidler, A. (1986). Culture in Action: Symbols and Strategies. American Sociological Review, 51(2), 273-286. https://doi.org/10.2307/2095521

Vajda J. (2006). A terápiás hatás mint melléktermék. Thalassa, 2006(17), 123-136. 